\title{
Heroes as Human Beings: An Interpretation of the Soviet Film "The 41st"
}

\author{
Mengran $\mathrm{Tao}^{1, *}$ \\ ${ }^{1}$ School of Literature and Journalism, Sichuan University, Chengdu, Sichuan 610065, China \\ ${ }^{*}$ Corresponding author. Email: 429781592@qq.com
}

\begin{abstract}
The "new wave" of Soviet film is the second development peak in the history of Soviet film. It inherits the achievements of predecessors in the 1920s in technological form innovation, and creates a creative concept with humanitarianism as the core in theme expression. "New wave" is not the product of "Anti Leftism" and "Anti Socialist Realism". Its emergence is to rectify the rigid creation "routine" of the Soviet Union in wartime and postwar, and to some extent, it improves the creation method of socialist realism. With the help of "cultural thaw", the director Chuhley boldly abandoned the creation mode of "pure socialist realism film" which has almost become hypocritical, and successfully created this work with profound thought and poetic flavor. He gave attention and sympathy to the little people in the war and created a group of "heroes as human beings". His work "The 41st" perfectly takes into account the understanding, education and aesthetic functions of film art, and reaches a high level in poetic expression and human exploration. Therefore, it has become an unavoidable milestone in the study of the "new wave" of Soviet films.
\end{abstract}

Keywords: Soviet films, New wave, Gregory Chuhley, Humanitarianism.

\section{INTRODUCTION}

If the audience is asked to select the most classic Soviet love film, I believe that many people's choice is "The 41st" (Сорокперона). This film fully shows the unique style and charm of the Soviet love film which is different from other countries' films of the same type. Compared with the films of other countries, the films of the Soviet Union are quite different at all levels. To some extent, it is more similar to the minority art films than the commercial films whose main purpose is to make profits. With political propaganda as the highest task of film creation, and with Russia's profound cultural tradition strongly supporting it, Soviet films have had more humanistic feelings than most commercial films since their birth. In addition, because of the innovative consciousness of director Gregory Chuhley (регори чухле), and the characteristics of ideological propaganda emphasized in Soviet films, the love story between the sharpshooter and the White Army Lieutenant has changed from the "regular" love between the children and the women to the entanglement and sadism between love and class struggle till the destruction. Whether it's the Lieutenant's heart journey from "enemy of the people" to "my dear blue eyes" in Maliutka's heart, or Maliutka's heart breaking crying with "blue eyes" on his knees in the sea, it makes the audience tense again and again. Soundtrack also contributes a unique force to the film's tension. The film creates a wonderful atmosphere in which the audience is tense and intoxicated with various instruments and even vocals. Music changes with the development of the plot, from calmness to lyricism to rapidity. It slowly introduces the audience into the love story between Maliutka and the Lieutenant, making the audience feel the reality of being in the "first perspective". The film has a strong internal tension. The distinctive personas and skillful scene switching make the audience keep attention from the beginning to the end.

Being chased by the White army, Captain Yeshukov led marksman Maliutka, captured white lieutenant and other Red Army soldiers to escape into the desert. The day and night of the journey made Maliutka love Lieutenant Bai, but also shook her "class values". With the constant struggle between love and class consciousness, the knot of 
love and class struggle in the heart of the goddess gunner is more and more tightly bound, which eventually leads to the tragedy.

The conflict between class and love not only bothers Maliutka, but also makes the audience feel heavy. This movie throws a puzzle to the audience: is love and class position irreconcilable? This kind of love mixed with contradictions and entanglements makes the audience have to face up to the question of which is right or wrong between love and political ideal. The highlight of the film is to arouse people's deep thinking on relevant issues through the expression of human conflicts. In a word, the plot design is ingenious, the characters are vivid and the main idea is profound, which are all important factors for the success of the film.

\section{THE PAST AND THE PRESENT OF "THE 41ST"}

The symbol of its success in the world is that it won the special award of the 10th Cannes International Film Festival with its "amazing content, humanitarian feelings and poetic atmosphere". Although the domestic films before the "new wave" of the Soviet Union had the advantages of official funding and grand scenes, its "strong" political color also hindered its recognition by the mainstream film industry in Europe and the United States. However, with the "cultural thaw" after Stalin's death, it is undeniable that there are also political considerations in the mainstream western film industry in the 1950s when Khrushchev's secret report accepted the film. Western politicians may try to use the movie to show some "class harmony" thought to prove that under the pressure of the Soviet authorities "rule", the freedom and happiness of ordinary people are not guaranteed.

The repudiation of "The 41st" in the Soviet Union was directly related to the political ecology. From Stalin's death to Brezhnev's tightening of ideological control for more than ten years (that is, the period of the "new wave" of Soviet literature and art known to the outside world), art forms such as literature and film have developed completely different styles from the "Stalin style" socialist realism. Generally speaking, the ultimate pursuit of this "new style" is the humanitarian spirit. The literary works in this period pay attention to the life of ordinary people in the war, and reject the "perfect almost hypocritical" heroic leader image. In terms of technological innovation of film language, many directors in the new wave period will combine lyrical "poetry film" with plot description "prose film". In addition, the practical application of long lens has also been deepened and developed: it is more used as a lyric rather than just as a landscape tool. All of the above facts show that it is no accident that a large number of films with good quality and creativity emerged in the Soviet Union at this time. Many later generations even thought that the contribution of the Soviet film "new wave" to the world film history could only be matched by "New Hollywood".

In "The 41st", the director gives attention and sympathy to the little people in the war. The film truly describes the cruelty of war and how it destroys the lives of ordinary people. The gloom of life and the weakness of human nature should not be avoided. This is the "hero as a human being" with courage and responsibility, weakness and wavering, the blood of protecting the country and the indecision of abandoning love.

During the "new wave" period of the Soviet films, the creative features of introspection and humanitarianism were gradually suppressed in the increasingly tight political atmosphere in the 1960s until the low tide (marked by the ban of "women political commissar"). The appearance of "new wave" films in the Soviet Union is also like a meteor, which has made a brilliant and short "stroke" in the long history of Soviet films. Generally speaking, "The 41st" perfectly takes into account the understanding, education and aesthetic functions of film art, and reaches a very high level in poetic expression and human exploration. Therefore, it has become an unavoidable milestone in the study of the "new wave" of Soviet films.

\section{PLOT DESIGN AND CHARACTERIZATION}

As Gregory Chuhley's first work, "the forty first" has received great attention since it was put on the screen in 1957. This film has milestone significance in the development of Soviet love films. It not only vividly shows the superb shooting skills of the montage School of the Soviet Union, but also shows deep humanitarian feelings. The plot of this film is reasonable and ingenious: from the desert March to the sea disaster, from the island survival to the tragic ending, Gregory Chuhley shows the advantages of his good plot design incisively and vividly. The peace in the desert, the intensity in the raging waves, the tranquility on the island and the sadness of the ending together constitute a kind of "weak-sub strong-weak-strong" 
musical layout, thus showing great drama and "rhythm movement". The "weak rise" part begins with the leader Yeshukov leading the surviving Red Army soldiers and White Army prisoners to retreat to the Kragumo desert. In order to break through the encirclement of the enemy, the soldiers endured the pain of lack of water and food, and exposure to the sun, and marched hard in the desert step by step. In the abominable environment like purgatory, the director designed this part to be a relatively calm section. Of course, this kind of peace is full of depression and despair. "Sub strong" section is a shipwreck. When the survivors reached the Aral Sea, the captain ordered Maliutka and two Red Army soldiers to escort the white lieutenant to the headquarters by sea. The voyage was a complete nightmare: the boat was smashed by the bad waves caused by the storm, and only the white lieutenant and Maliutka survived. The two people who survived the disaster were finally washed into an uninhabited island by the sea water. In order to restore the reality of the shipwreck, the director used a large number of visual (heavy rain and ship swing) and auditory (intense "sharp" soundtrack and wind and waves) elements. This "sub strong" section played a good transition role between the relatively calm "desert March" and "island time". The next "weak section" is "the calm before the storm": the island with a closed environment and poor materials has become a love paradise for the couple to cultivate feelings. In the process of getting along with each other day and night, they kept getting to know each other. Maliutka gradually found something beyond the "all evil" class identity from the lieutenant - he not only has "lovely blue eyes", but also has many excellent qualities such as erudition and elegance, which made Maliutka gradually have a good feeling for him and fall in love with him. However, under the surface of sweetness, there is also a deepening value conflict between the two, which is manifested by their frequent quarrels. In this plot, the director turns the deepening conflict into a "buffer zone", which plays a "leading role" in the fierce tragic ending. The "end" of the "musical layout" of the film story is the climax of the plot development: the arrival of a White army ship broke their peaceful life. The lieutenant excitedly called for help from the White army at sea. When Maliutka saw this scene, the "string of class struggle" in his heart tightened again. His hatred of class enemies overwhelmed his yearning for love. Then he shot "blue eyes" and killed them. The ending plan of "suddenly ending" after a long tense struggle was very ingenious unexpected and memorable.
The successful portrayal of the characters is also one of the important factors for the film to become a classic. In addition to the arrogant and ugly white soldiers, the main characters in the film, such as the Red Army commissar, Maliutka and the captured lieutenant, are very real and vivid. The director tries to show the cruelty of the war and the ordinary people in the war from the perspective of human nature, so it is very important to make the characters true and "de facial makeup". Political commissar Yeshukov impressed many viewers. As a team leader, he fully possesses the perseverance quality of leaders. When fighting against the enemy, he was the first to fight bravely; when leading the team to break through, he also worked hard, which was powerful and trustworthy. In addition, Yeshukov charm lies in his "wise Jianghu spirit" -- he often scolds lazy and pessimistic soldiers and likes to grumble and swear when he doesn't want to, which makes the audience feel that he is very friendly. The formation of Lieutenant Bai as the "leading man" in the White army was also painstaking: he was a typical noble intellectual. On the one hand, he has almost all the problems of aristocracy: luxury of life (owning and liking villas and yachts), arrogance; on the other hand, he is as gentle as an intellectual, keen on reading (he was a professional or amateur linguist before the war, and his family has a rich collection of Books) and respect for culture. For class struggle, he has a dismissive attitude that class struggle and war are just "stupid games". The lieutenant himself pursues what he considers to be "the noblest" knowledge, art and beauty. He wants to go to a quiet place with Maliutka and live, "let Maliutka go to school and get rid of the rough life". There is no clear gap between different classes in the lieutenant. These "so-called" class struggles seem to him to be the culprit of destroying the happy life. They have no value at all. Maliutka is not only one of the core protagonists, but also the center of many contradictions in the film: Although the rural girl is rough and has little writing, she also has her own artistic pursuit - often reciting and creating poetry (even in the process of war), and she also has a certain appreciation for the rhythm and artistic conception of poetry. Her pursuit of the communist ideal is firm. He denounced that the "peaceful life" pursued by the lieutenant was based on the "bones of the working-class people". On the other hand, as a young girl, love is very attractive to her. It is the endless struggle between the two that makes Maliutka miserable and in a dilemma, which eventually leads to the tragedy. 


\section{TORTURE OF HUMAN NATURE AND CARE OF HUMANITARIAN}

Two levels of struggle in the film continue to cross development: the battle between the Red Army and the "white bandits" and the struggle between Maliutka's political ideals and love. Many people think that although the Lieutenant's ideal has some negative aspects (less concern for the wellbeing of the people), his desire for peace is desirable. A large part of the common people may share the same view with the lieutenant - oppose the war and pursue a comfortable and peaceful life. It's hard to deny the wishes of the lieutenant, let alone the lofty ideals of Maliutka. Because of this, their contradictions cannot be resolved, and the "knot" of this contradiction can only be more and more tied with the advance of the plot.

Although the films in the "new wave" period of the Soviet Union still bear the common ideological "mark" of the Soviet films, in terms of their ideological and spiritual connotation, they have a strong tendency to return to the "Slavic humanitarianism" tradition. The typical example is "The 41st" refers some creative methods of the classic Russian writers in the period of Emperor Russia, especially Dostoevsky ( $\Phi$ д орДосто евский). There is a very important feature in Dostoevsky's novels, that is, he always intentionally or unintentionally lets the characters debate each other with opposite or even incompatible ideas (such debates often have no final conclusion and win or lose). In this way, Dostoevsky constantly "brainwashed" the readers. Surprisingly, he often succeeds. The readers find that their existing value system is gradually "loose" or even disintegrated under his "guidance". However, like Nietzsche, Dostoevsky's way of thinking and expression "destroyed the old values, but failed to stable the new values." The charm of this way of thinking and expression does not lie in the creator's need to establish or consolidate a certain value through an art work. Dostoevsky, by throwing out many contradictory "truths" at the same time, makes readers constantly "torture" them. Through thinking, questioning and even reevaluating these values, readers' spirit and soul can be purified and sublimated. No doubt, "The 41st" draws on this method of expression: in front of the different values of Lieutenant Bai Jun and Maliutka, the director does not deliberately favor one side. In the movie, both the male and female protagonists are trying to "preach" their ideas in order to persuade the audience. When the audience is still struggling to judge their right and wrong, Maliutka interrupts our choice with a bullet.

Great works of art will convey a kind of positive thought which is good for all mankind. Although the game between love and political ideals in the film fails to distinguish the winner from the loser, we can also get some insights through their thinking: in this peaceful period, people always underestimate the value of "ordinary things" such as friendship, love and family. However, in some "special" times, it is hard to get these seemingly ordinary things. These pure affection and love are often suppressed in the harsh political atmosphere. After such thinking, maybe we will cherish today's peaceful environment and the friendship, love and family that we regard as "deserved". At the very least, we don't have to make painful choices and sacrifices between political ideals and love, as Maliutka did. From the perspective of ideological expression, it is one of the important ideological heritages of Russian democracy in the 19th century that people first suffer from the loss of value and then lead them to gain "Enlightenment" in the way of "torture" value. In addition, this kind of literature tradition of attaching importance to human nature is also an important reason why Russian realism literature in the 19th century was hailed as "the third highest literary peak in the world".

\section{CONCLUSION}

As recognized by the international film critics as the leader of the "new wave", the significance of "The 41st" to the "new wave" of Soviet films is self-evident: it "announced" the arrival of the second "golden age" of Soviet films with its "shocking" language innovation and creative new ideas. At the same time, it also points out the creative direction for other directors of the "new wave" - to create a "new era Soviet movie" which combines warm humanitarianism with full poetry, transforms content and form into one, and integrates perfectly. "The $41 \mathrm{st}$ " is closely related to the late Soviet films, the "third development peak of Soviet films" in the 1980s and the new Russian films after the disintegration. From it, we can also see a "vein" and internal logic of the development of Soviet films in the later 50 years of the 20th century. In the author's opinion, although the Soviet film often appears "periodic retrogression" in the development process due to political ecology and ideology and other factors, the theoretical and practical wealth accumulated in each "golden 
period" of development cannot be "submerged" by the "left leaning law order" for a while, and the new creative ideas (humanitarianism customs) emerged in the "new wave" period. Huai, his attention to "the middle and small people in the big era" and the innovation of language and Technology (the development of poetic films and "emotional photography") all laid a solid theoretical and practical foundation for the development of Soviet films and the Renaissance of new Russian films. Therefore, our research on the "new wave" of Soviet films should continue to be in-depth, which is of great academic significance to grasp the internal relationship between Soviet film history and its various stages as a whole.

\section{AUTHORS' CONTRIBUTIONS}

This paper is independently completed by Mengran Tao.

\section{REFERENCES}

[1] Feng Jie. The Soviet Model and the Construction of China's Foreign Film Trade Mechanism in the "17 Years" Period [J]. Contemporary Film, 2013(11): 66.

[2] Hong Zicheng. Revisionism Meets Dogmatism: Criticism of Soviet Film in 1963[J]. Chinese Contemporary Literature Research, 2020(3).

[3] Li Xiaozheng. Poetry and Film of the Soviet Union [J]. Film Art, 1986 (12).

[4] Liang zanovsky. History of Russia (Eighth Edition) [M]. Trans. Yang Ye, Qing Wenhui, Wang Yi. Shanghai: Shanghai People's publishing house, 2017.

[5] Ma Longshan. The History of the Cultural System of the Soviet Union [M]. Beijing: China Social Sciences Press, 1996 Edition, 264.

[6] [Shen Zhihua. Rise and Collapse of a Great Power: a Special Study on Soviet History (1917-1991) [M]. Beijing: Social Sciences Literature Press, 2018.

[7] Wu Hanqing. Diversification of Styles, Schools and Means of Expression in Soviet Modern Films [J]. World Film, 1983 (04).

[8] Wu Xiaoli, Zhang Chengjie. Soviet Film Course [M]. Shanghai: Fudan University Press, 2010.
[9] Zhu Hongqiong. "The 41st" in the Field of Acceptance [D]. World Literature Review, 2010 (1): 81-84. 